\title{
АНДРЕЙЧИН М.А. ІНФЕКЦІї І ЛЮДИ : РОЗМИСЛИ КЛІНІЦИСТА / М.А. АНДРЕЙЧИН. - ТЕРНОПІЛЬ : НАВЧАЛЬНА КНИГА - БОГДАН, 2020. - 256 с.
}

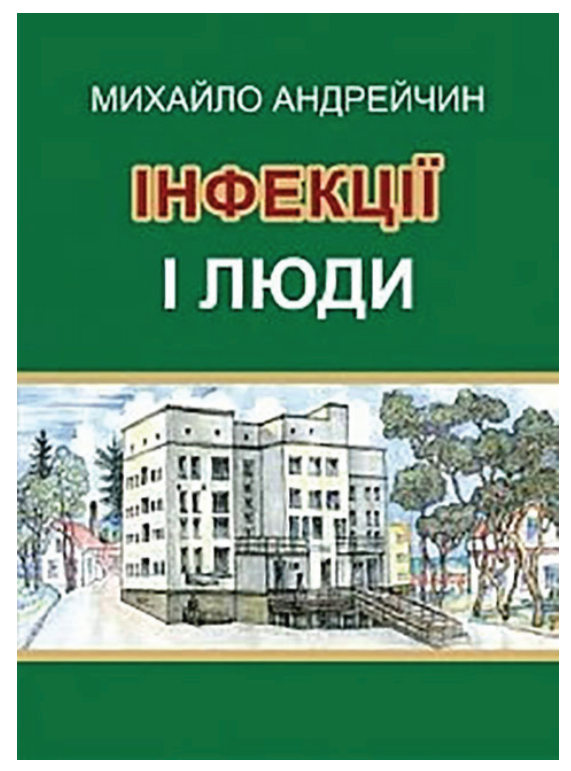

У рецензії вказано на основні положення книжки споминів відомого лікаря-інфекціоніста і науковця М.А. Андрейчина, зокрема його кредо «у кожному хворому бачити людину». Позитивно оцінено чікаві розповіді про конкретних хворих, особливості їх недуги і поведінки, успіхи та недоліки в лікуванні.

Ключові слова: спогади лікаря, інфекційні хворі.

Побачила світ чудова книжка спогадів і клінічних роздумів лікаря-інфрекціоніста, профресора, академіка НАМН України Михайла Антоновича Андрейчина «Інфекції і люди», в якій автор відтворив різні періоди свого життя i праці, що формували його як лікаря та багатогранну особистість.

У книжці наш колега в захопливій, відвертій і доступній формі виклав своє просресійне становлення і творчий шлях від клінічного ординатора до академіка, з акцентом на лікарську практику. Читаючи спомини сивочолого професора, мимовільно виникає бажання порівняти своє життя і долю з викладеними фрактами $з$ життя й праці автора, тому що його внесок в інфекційну службу нашої країни вагомий і незаперечний. Все наведене - яскравий приклад служіння людям, колегам і суспільству в цілому.

Думаю, що багато колег і пацієнтів, які спілкувалися 3 Михайлом Антоновичем, запримітили його ерудицію, інтелігентність, доброту і душевність. І всі ці людські якості підтверджені змістом книги. Автор ділиться своїм багатим досвідом, що фрормує практичну фрілософрію лікаря-інорекціоніста. Ця ошатна книжка насамперед про лікаря, про відданість вибраному шляху, а не тільки про інфекції як такі.

Видання містить вступ і сім розділів з такими оригінальними назвами: «Молода жага творчого пошуку», «Коли печінка просить допомоги», «Якщо хворого лихоманить», «Загадкова недуга та людські долі», «Заразитися можна через їжу та воду», «Пам'ятник святому Роху - покровителю інсрекційних хворих» і «Цей нескінченний калейдоскоп інсекційних хвороб». У загальну канву розповіді про окремих хворих, яким надавалася медична допомога, органічно вплетена стисла інорормація про виконані наукові дослідження, переважно дисертаційні.

У вступі автор ділиться з читачами своїми міркуваннями про надання допомоги інфекційним хворим у колишньому Радянському Союзі та теперішній незалежній Україні, справедливо критикує сучасні недоліки в діагностиці, лікуванні та профрілактиці інфекцій, обумовлені вадами здійснюваної медичної рефрорми. Ознайомлюючись із наступними розділами можна збагнути специфріку роботи іноекціоніста й клінічне різноманіття проявів інфекційних хвороб, що диктує необхідність індивідуального підходу лікаря до кожного пацієнта. Автор наводить яскраві спогади про багатьох пацієнтів, яким допомагав за різних обставин. Їх історії неоднакові, частіше закінчувалися видужанням, але й були трагічні. Водночас кожна повчальна, спонукає до співпереживання, чому сприяє вдало вибраний стиль оповіді. Особливої уваги варті численні метафори і влучні прикінцеві висловлювання щодо кожного наведеного спостереження. Пріоритет надано хворій людині та її долі.

Читача, без сумніву, заінтригує нарис «Загадкова недуга та людські долі», в якому висвітлено так звану хворо- 
бу Моргелонів, вивчення якої в Україні започаткував М. Андрейчин. Окремий розділ присвячено питанням духовності. Із захоплюючого сюжету можна довідатися про святого Роха - дуже шанованого в християнському світі покровителя інфекційних хворих і захисника від епідемій, спорудження йому в Тернополі оригінальної скульптурної композиції.

Викладені в книжці думки будуть спонукати колег, які вже пройшли або завершують професійний шлях іноекціоніста, оглянутися на минувшину та замислитись, а декого, можливо, навіть узяти кулькову ручку і написати свої мемуари. Практикуючим інсрекціоністам у складний час пандемії COVID-19 вона допоможе глибше осмислити важливість своєї праці і відповідальність перед хворими та суспільством. Ця книжка буде особливо корисною молодим лікарям і студентам, бо вказує ясний і чіткий шлях до профресійного успіху. Головне кредо книжки - «у кожному хворому бачити людину».

\section{ANDREYCHYN M.A. INFECTIONS AND PEOPLE : THE THOUGHTS OF A CLINICIAN / M.A. ANDREYCHYN. - TERNOPIL: NAVCHALNA KNYHA - BOHDAN, 2020. - 256 p.}

\section{M.S. Suremenko}

Dnipro Medical Academy

SUMMARY. This review devoted to the book of memoirs of the famous infectious disease doctor and scientist M.A. Andreychyn. His credo is "to see a person in every patient". Interesting stories about specific patients, features of their illness and behavior, successes and lacks in treatment were positively evaluated.

Key words: doctor's memoirs; infectious patients.

\section{Відомості про автора:}

Суременко Микола Степанович - к. мед. н., доцент кафредри інфекційних хвороб дз «Дніпровська медична академія»; e-mail: suremenko123@gmail.com

\section{Information about the author:}

Suremenko M. S. - PhD (Medicine), Associate Professor of the Infectious Diseases Department, Dnipro Medical Academy; e-mail: suremenko123@gmail.com

Конфрлікт інтересів: немає.

Author has no conflict of interest to declare.

Отримано 2.09.2020 p 